\title{
Human Rights and Space: Reflections on the Implications of Human Activity in Outer Space on Human Rights Law
}

\author{
Danielle Ireland-Piper* \& Steven Freeland** \\ DOI: 10.21827/GroJIL.9.1.101-127
}

\begin{abstract}
Keywords
OUTER SPACE; HUMAN RIGHTS; INTERNATIONAL LAW; TECHNOLOGY; EXTRATERRITORIAL
\end{abstract}

\begin{abstract}
What are the implications of human activity in outer space for international human rights law? In this article, we reflect on these questions with a view to advancing dialogue on the intersection between space law and human rights. We do so by considering the impact of extra-terrestrial human activities such as access to space and remote-sensing activities, space debris, space mining, the weaponisation and militarization of space, and the assertion of criminal jurisdiction extra-terrestrially. Ultimately, we conclude that human activity in space has significant consequences for the advancement of human rights. While, in our view, existing legal frameworks on international human rights law apply extra-terrestrially, there is still scope for specialist frameworks guarding human rights law in the context of human activity in outer space.
\end{abstract}

"To confine our attention to terrestrial matters would be to limit the human spirit."

Stephen Hawking, Astrophysicist

"Space is for everybody. It's not just for a few people in science or math, or for a select group of astronauts. That's our new frontier out there, and it's everybody's business to know about space."

$\sim$ Christa McAuliffe, Teacher and Challenger Astronaut

\section{Introduction - a Confluence of Two Regimes}

In its 2004 advisory opinion, Legal Consequences of the Construction of a Wall in the Occupied Palestinian Territory (Wall Opinion), ${ }^{1}$ the International Court of Justice held that a State party to the International Covenant on Civil and Political Rights remains legally bound to comply with its provisions, even when exercising jurisdiction outside its national territory. ${ }^{2}$

* Associate Professor of Law, Bond University.

** Emeritus Professor of Law, Western Sydney University; Professorial Fellow, Bond University. Our sincere thanks are owed to Jane Andrews for her excellent research and editing assistance. Thanks also to the blind peer reviewers for their helpful comments which served to improve our work.

1 Legal Consequences of the Construction of a Wall in the Occupied Palestinian Territory (Advisory Opinion) [2004] ICJ Rep 136 (Wall Opinion).

2 ibid 179. Israel was found to be bound by its obligations under the International Covenant on Civil and Political Rights on the basis that it was exercising a type of territorial jurisdiction over Occupied Palestine; see, also, the decision of the European Court of Human Rights in the case of Bankovic and Others $v$ Belgium and Others App no 52207/99 (ECtHR, 12 December 2001). In that case, an application by six citizens of the Federal Republic of Yugoslavia asserted that the bombing of a radio and television building by North Atlantic Treaty Organisation (NATO) during the Kosovo crisis in April 1999, in which a number of people were killed, violated the right to life in art 2, and the freedom of expression in art 10, of the Convention for the Protection of Human Rights and Fundamental Freedoms (European

This work is licensed under the Creative Commons Attribution-NonCommercial-NoDerivatives 4.0 International License. To view a copy of this license, visit http://creativecommons.org/licenses/by-nc-nd/4.0/. 
What, then, is the relationship between outer space (which by definition is regarded as an area beyond national jurisdiction) and international human rights law? What implications does inevitable increasing human activity in space have on the realisation of and adherence to human rights norms? As observed by the United Nations General Assembly in its Declaration on the Use of Scientific and Technological Progress in the Interest of Peace and for the Benefit of Mankind:

... while scientific and technological developments provide ever increasing opportunities to better the conditions of life of peoples and nations, in a number of instances they can give rise to social problems, as well as threaten the human rights and fundamental freedoms of the individual. ${ }^{3}$

Space has relevance for many aspects of human life. For example, remote sensing technologies can be useful to health, agriculture, environment, disaster management, education, transportation, communication, and humanitarian assistance. There is also some speculation that, at some point in human history, outer space will include 'colonies [we think that this is perhaps more accurately to be described as 'permanent settlements'] established, operated, and populated ${ }^{4}$ by humans.

Human activity in outer space may also bring with it the darker side of human nature - including the potential for human rights abuses and armed conflict. Sadly, 'one enduring characteristic of humankind since its existence on Earth has been its willingness to engage in intraspecies warfare' ${ }^{5}$ Nonetheless, space also brings possibilities for the improvement of knowledge, science, and other beneficial developments for humanity.

In these respects, outer space asserts a far greater influence upon the directions taken by humankind than one might at first instance imagine - yes, the exploration and use of outer space has been designated as the 'province of [hu]mankind', ${ }^{6}$ but outer space is not only a place for us to venture to in order to explore and exploit. Our myriad uses of outer space have real impacts upon all on Earth every day of our lives. This is expressly recognized, for example, in the preamble of the Outer Space Treaty, paragraphs 2 and 3 of which confirm that, at the time these principles had been codified, the international community had:

Recogniz[ed] the common interest of all mankind in the progress of the exploration and use of outer space for peaceful purposes,

and

Convention on Human Rights, as amended) (ECHR). The Court declared the application inadmissible on the basis that there was no jurisdictional link between the victims of the act and the respondent States. For background to the bombing, see Steven Freeland 'The Bombing of Kosovo and the Milosevic Trial: Reflections on Some Legal Issues' (2002) Australian International Law Journal 150.

3 UNGA Res 3384 (1975) GAOR 30 ${ }^{\text {th }}$ Session Supp 16.

4 Taylor Hardenstein, 'In Space, No One Can Hear You Contest Jurisdiction: Establishing Criminal Jurisdiction on the Outer Space Colonies of Tomorrow' (2016) 81 Journal of Air Law and Commerce 251, 282.

5 Steven Freeland and Ram S. Jakhu, 'Promoting Peace from Above? Utilising Space for the Prevention and Prosecution of Human Rights Violations' in Aram Daniel Kerkonian (ed) Global Space Governance and the UN 2030 Agenda (McGill 2019) 22.

6 See Treaty on Principles Governing the Activities of States in the Exploration and Use of Outer Space, including the Moon and Other Celestial Bodies (adopted 27 January 1967, entered into force 10 October 1967) 610 UNTS 205 (Outer Space Treaty) art 1. 
Believ[ed] that the exploration and use of outer space should be carried on for the benefit of all peoples irrespective of the degree of their economic or scientific development

In essence, the international legal regulation of outer space is founded on an assumption that space was (at the time) a new frontier and this raised important issues about humanity. We hold the firm view that this is still the case, despite the realities associated with the rapid diversification of space activities to incorporate, for example, military uses, and the increasing involvement in outer space of commercial (private) enterprise, whose agendas may not match up entirely with a spirit of sharing and community.

Given this obvious 'human' face to space activities (both as to cause and effect), it is therefore quite surprising that the interaction and intersection between the specific international legal regime of outer space and the international legal regulation of human rights has not been the subject of greater considered scholarship in the past. Apart from a small number of interesting commentaries, ${ }^{7}$ these two legal paradigms have largely been considered in isolation, even though their formal codification coincided from a temporal viewpoint, and even though the same actors were involved in the detailed conversations and negotiations that led to their finalization.

The two legal regimes are largely products of the post-Second World War period. From the perspective of outer space, the late 1940s saw a ratcheting up of distrust between the 'west' and 'east', giving rise to diplomatic tensions and, ultimately, the onset of the 'Cold War'. This geopolitical rivalry saw the two main protagonists, the Soviet Union and the United States, intensify their efforts to build upon the weapons-related technology that had been developed during the war period, including in the area of rocket technology. Both superpowers made significant strides towards developing space capabilities, and devoted significant resources towards that end.

In the end, on 4 October 1957, a Soviet space object, Sputnik I, was launched and subsequently orbited the Earth over 1,400 times during the following three-month period. This milestone heralded the dawn of the space age, the space race, and the legal regulation of the use and exploration of outer space. There then followed an intense period of international discussion and consideration of how best to provide for a framework of legal principles to regulate human activities in outer space, culminating in the first instance in the Outer Space Treaty.

The Second World War had also starkly illustrated the horrors that flow from a gross and systematic violation of human rights and human dignity. Up until that time, there were barely any international instruments that addressed the concept or content of the fundamental rights of the individual. Indeed, the reference in the United Nations Charter to the international community's determination 'to reaffirm faith in fundamental human rights, in the dignity and worth of the human person, in the equal rights of men and women and of nations large and small', ${ }^{8}$ was in more practical terms recognition of the need to codify these rights as a first step towards the promotion and protection of those ideals, in order to have any chance of avoiding such catastrophes again (sadly, subsequent history suggests that we have thus far failed in this regard).

See for example Irmgard Marboe, 'Human Rights Considerations for Space Activities' in Stephan Hobe and Steven Freeland (eds), In Heaven as on Earth? The Interaction of Public International Law on the Legal Regulation of Outer Space (Institute of Air and Space Law of the University of Cologne 2013) 135. See also references at footnote 1 of that chapter.

8 Charter of the United Nations (adopted 26 June 1945, entered into force 1968) (UN Charter). 
The first stages of this human rights' 'movement' saw the conclusion of several very significant legal instruments that set out to codify the fundamental rights and freedoms that underpin international human rights law. The 'twin covenants' of $1966,{ }^{9}$ which incorporate into treaty form the principles set out in the 1948 Universal Declaration of Human Rights, ${ }^{10}$ were being negotiated - sometimes quite fiercely - while the same time that the space race had begun, and the most important ground-rules of space law were being developed.

In both instances, the same geopolitical rivalries and ideological differences shaped the final structure of each regime. A fact not often acknowledged is that the ICCPR and ICESCR were finalized by the United Nations General Assembly and opened for signature on 16 December 1966, just a matter of a few weeks before the Outer Space Treaty (27 January 1967).

The development of these two legal regimes also coincided with a process of decolonization, largely under the stewardship of the United Nations system. Both the UN Charter and the twin covenants make express reference to the right of self-determination of 'peoples', ${ }^{11}$ and this galvanized a momentum that ultimately led to the establishment of a significant number of new States in the period between the 1950s and 1970s, many of these in Asia and Africa. ${ }^{12}$ Most of these new States were established as a result of decolonization, and with this newly-won independence came the clear resolve of those States to be fiercely independent and to reject as much as possible the geopolitics and single-minded resource exploitation that had existed during the time of colonialism.

This stance is reflected, for example, by the opening paragraph of the Outer Space Treaty, which demands that the exploration and use of outer space is to be 'for the benefit and in the interests of all countries, irrespective of their degree of economic or scientific development'.

Nonetheless, this period was also characterized by an increasing divide, both in actual but also ideological terms, between what became known as 'developed' and 'developing' States - a division that formed an important, and sometimes controversial ${ }^{13}$

9 International Covenant on Civil and Political Rights (adopted 16 December 1966, entered into force 23 March 1976) 999 UNTS 171 (ICCPR); International Covenant on Economic, Social and Cultural Rights (adopted 16 December 1966, entered into force 3 January 1976) (ICESCR). Collectively these two instruments are often referred to as the 'twin covenants'.

10 Universal Declaration of Human Rights (adopted 10 December 1948) UNGA Res 217 A(III) (UDHR). Reference should also be made to other very significant treaties finalised at that time, including the Convention on the Prevention and Punishment of the Crime of Genocide (adopted 9 December 1948, entered into force 12 January 1951) 78 UNTS 277; Geneva Convention for the Amelioration of the Condition of the Wounded and Sick in Armed Forces in the Field (adopted 12 August 1949, entered into force 21 October 1950) 75 UNTS 31 (First Geneva Convention); Geneva Convention for the Amelioration of the Wounded, Sick, and Shipwrecked Members of Armed Forces at Sea (adopted 12 August 1949, entered into force 21 October 1950) 75 UNTS 85 (Second Geneva Convention); Geneva Convention Relative to the Treatment of Prisoners of War (adopted 12 August 1949, entered into force 21 October 1950) 75 UNTS 135 (Third Geneva Convention); Geneva Convention Relative to the Protection of Civilian Persons in Time of War (adopted 12 August 1949, entered into force 21 October 1950) 75 UNTS 287 (Fourth Geneva Convention); Convention for the Protection of Human Rights and Fundamental Freedoms (adopted 4 November 1950, entered into force 3 September 1953) 213 UNTS 221 (ECHR).

11 See UN Charter (n 8) art 1(2); ICCPR (n 9) art 1(1); ICESCR (n 9) art 1(1).

12 For example, at the time of the adoption of the UDHR (n 10) in 1948, the membership of the United Nations stood at 56. By 1967, when the 'twin covenants' (n 9) and the Outer Space Treaty (n 6) had been finalised, this number had more than doubled.

13 See Agreement Governing the Activities of States on the Moon and other Celestial Bodies (adopted 18 December 1979, entered into force 11 July 1984) 1363 UNTS 3 (Moon Agreement) art 11(7)(d). 
element in the formulation of various of the space law source documents. ${ }^{14}$ Moreover, the overall trusteeship of the two international legal regimes remains to a large degree (although not exclusively) within the United Nations; space law through the United Nations Committee on the Peaceful Uses of Outer Space (UNCOPUOS) and its secretariat the United Nations Office of Outer Space Affairs (UNOOSA), and human rights law through a series of Charter Bodies, including the Office of the High Commissioner for Human Rights (OHCHR), the Human Rights Council (which replaced the United Nations Commission on Human Rights in 2006) and the Economic and Social Council (ECOSOC), as well as various United Nations Treaty Bodies such as the Human Rights Committee, which was established to monitor compliance with the ICCPR.

In addition to their shared historical antecedents, the lack of a coordinated analysis of these coinciding regimes is also at odds with the structure of outer space regulation itself. It is undisputed that, from a 'legal rules' perspective, the international regulation of outer space - past, present and future - is 'embedded' in international law. It is not an esoteric and separate paradigm limited solely to the lex specialis of space law, which is based primarily on a series of United Nations Space Treaties. Whilst these instruments are, of course, the important baseline for the applicable legal framework, other aspects of international law, including the jus ad bellum, international environmental law, international air law and international trade law, are all relevant and may provide guidance to resolve space-related issues and disputes. In a sense, this is an obvious point, particularly given the complexity of human activities in space and their impacts on all of us, but one that is worth emphasizing.

The space-related instruments cannot and do not purport to provide a comprehensive legal framework for every activity, nor for every contingency that may arise. It has often been noted that, whist it is clear that the fundamental principles in the UN Space Treaties, particularly the Outer Space Treaty, are relevant and applicable to all space activities, there are lacunae within these instruments with respect to the specifics of many space activities, a trend that continues to increasingly show itself as new uses of space are being contemplated, developed and undertaken that would almost certainly have been outside of the contemplation of the drafters of those documents in the 1960s and 1970s.

For example, since that time, seven private citizens or 'space tourists' have paid to go to space. ${ }^{15}$ On 13 December 2018, Virgin Galactic, conducted their first trip to 'nearspace' with Virgin's spaceplane VSS Unity reaching an altitude of 82.7 kilometers (51.4 miles). ${ }^{16}$ There is now considerable interest in mining natural resources in space and legal debate as to whether - and the extent to which - that is permitted. In short, the development that will ultimately enable activities like space mining and large-scale space tourism to be undertaken will create interactions between humans and states which the existing treaty regimes simply did not anticipate.

14 See for example UNGA Res 37/92 (1982) GAOR 37th Session Supp 51 (Broadcasting Principles) principles 2, 6, 11; UNGA Res 41/65 (1986) GAOR 41 ${ }^{\text {st }}$ Session Supp 53 (Remote Sensing Principles) principles II, IX, XII, XIII; UNGA Res 47/68 (14 December 1992) UN Doc A/SPC/47/L.6 (Principles to Use of Nuclear Power Sources in Outer Space) principle 7(2)(b); UNGA Res 51/122 (1996) GAOR $51^{\text {st }}$ Session (Use of Space for Benefit and Interest of All States).

15 'Space tourists paying $\$ 71$ million each to be first all-private International Space Station Crew' $A B C$ News Online (27 January 2021) <https://www.abc.net.au/news/2021-01-27/1st-private-space-crew-paying$71 \mathrm{~m}$-each-to-fly-to-station/13096360>

16 Mike Wall, 'Virgin Galactic's SpaceShipTwo Reaches Space for 1st Time in Historic Test Flight' (Space, 13 December 2018) <https://www.space.com/42716-virgin-galactic-spaceshiptwo-unity-reachesspace.html> 
Notwithstanding the continuing applicability of the fundamental framework of space principles, in such cases, were the need to arise, it would often become necessary to draw upon other areas of (international) law to resolve a particular dispute.

This is also a logical consequence of the wording of article III of the Outer Space Treaty, which requires that activities in the exploration and use of outer space are to be carried out 'in accordance with international law, including the Charter of the United Nations'. Various authors have previously sought to highlight this point in relation to other international law contexts, ${ }^{17}$ and it remains no less relevant when it comes to the relationship between the regulation and conduct of outer space activities and the fundamental human rights of individuals on Earth.

In this article, we reflect on these questions with a view to advancing dialogue on the intersection between space activity, space law, and international human rights law. We do so by considering the impacts of certain aspects of extra-terrestrial activity, including access to space, remote sensing-activities, the increasing implementation of artificial intelligence into space technology, space debris, assertions of criminal jurisdiction in outer space, space mining, and the weaponisation and militarization of space. Each of these activities is briefly described and then its relationship with, and/or implications for human rights is considered.

First, and by way of background, we 'recap' the premise of international human rights law and the fundamentals of space law. This is not intended as a complete analysis of either body of law but rather is simply undertaken by way of 'scene-setting' for our analysis in the substantive parts of this article.

\section{Background}

\section{A. Recapping Human Rights Law}

We do not purport to provide a comprehensive summary of all aspects of international human rights law in this background section, and nor would that be possible. Rather, we instead include a brief overview of the basic frameworks of international human rights law, so as to equip a person not familiar with the relevant principles with a basic understanding of the relevant (at least for the purposes of this article) foundational instruments and mechanisms and basic human rights literacy.

At its most basic, to have a right is to have a claim recognised by the relevant governing rules. The relevant 'rules' of human rights law include a number of international treaties, as well as customary international law, and regional and domestic law.

\section{i. Sources of international human rights law}

As a starting point, the Charter of the United Nations, which came into force on the 24 October 1945, opens with a commitment to 'reaffirm faith in fundamental human rights, in the dignity and worth of the human person, in the equal rights of men and women and of nations large and small'. This language was subsequently adopted in the Preamble of Universal Declaration of Human Rights (UDHR) in 1948, along with a 'recognition of the inherent dignity and of the equal and inalienable rights of all members of the human family is the foundation of freedom, justice and peace in the world' and that 'human rights should be protected by the rule of law'.

17 See for example Ram Jakhu and Steven Freeland, 'The Relationship between the United Nations Space Treaties and the Vienna Convention on the Law of Treaties' in Scott Hatton (ed) Proceedings of the International Institute of Space Law (Eleven International Publishing 2012) 375; Ram Jakhu and Steven Freeland, 'The Sources of International Space Law' in Scott Hatton (ed) Proceedings of the International Institute of Space Law (Eleven International Publishing 2013) 461. 
The $U D H R$ is one of the key instruments that make up the International Bill of Human Rights, ${ }^{18}$ along with the International Covenant on Civil and Political Rights (ICCPR $)^{19}$ and the International Covenant on Economic, Social and Cultural Rights (ICESCR), ${ }^{20}$ which both came into effect in 1976. For breaches of the ICCPR, individuals can institute proceedings before the Human Rights Committee, ${ }^{21}$ and an individual complaints mechanism is provided for in an optional protocol to the ICESCR came into force in $2013 .{ }^{22}$ Human rights mechanisms are also present at the regional level. ${ }^{23}$

As a matter of international law, however, a treaty is only binding on states that have ratified. Article 34 of the Vienna Convention on the Law of Treaties expressly provides that 'A treaty does not create either obligations or rights for a third State without its consent'. However, the Vienna Convention also affirms in Article 38 that a non-party to a treaty containing a particular norm can still be bound by a similar norm found in customary international law. Sources of human rights obligations can be found at customary international law (which itself is made out by both a) established state practice and $b$ ) opinion juris, the belief of states they are bound) as well as in regional and domestic human rights law. For example, rights recognised under customary international law include a prohibition against torture, the prohibition against genocide, the right of selfdetermination and principles of fair trial.

\section{ii. Positive and negative rights}

Human rights law includes both positive obligations and injunctions on particular types of state interference. For example, the rights contained in the ICCPR are commonly treated as rights which should be free from State interference, such as freedom of movement, peaceful assembly, the freedom of thought and religion, equality before the law, and prohibitions on practices such as torture, slavery, and arbitrary arrest and detention. By

18 Note, there are, however, a plethora of other international agreements relating to human rights, including the International Convention on the Elimination of All Forms of Racial Discrimination (adopted 32 December 1965, entered into force 4 January 1969) 660 UNTS 195 (ICERD); Convention on the Elimination of All Forms of Discrimination against Women (adopted 18 December 1979, entered into force 3 September 1981) 1249 UNTS 13 (CEDAW); Convention against Torture and Other Cruel, Inhuman or Degrading Treatment or Punishment (adopted 10 December 1984, entered into force 26 June 1987) 1465 UNTS 85 (CAT); Convention on the Rights of the Child (adopted 20 November 1989, entered into force 2 September 1990) 1577 UNTS 3 (CRC); and Convention on the Rights of Persons with Disabilities (adopted 13 December 2006, entered into force 3 May 2008) 2515 UNTS 3. Further, a number of the foundational conventions have associated optional protocols, such as the Optional Protocol to the International Covenant on Economic, Social and Cultural Rights (adopted 10 December 2008, entered into force 5 May 2013) UN Doc A/64/435 and the Optional Protocol to the International Covenant on Civil and Political Rights (adopted 16 December 1966, entered into force 23 March 1976) 999 UNTS 171.

$19 \operatorname{ICCPR}(\mathrm{n}$ 9).

$20 \operatorname{ICESCR}(\mathrm{n}$ 9).

21 Office of the High Commissioner of Human Rights, 'Monitoring civil and political rights' (United Nations Human Rights, 16 July 2014) <http://www.ohchr.org/en/hrbodies/ccpr/pages/ccprindex.aspx>

22 Office of the High Commissioner of Human Rights, 'Committee on Economic, Social and Cultural Rights' (United Nations Human $\quad$ Rights, $16 \quad$ July <http://www.ohchr.org/en/hrbodies/cescr/pages/cescrindex.aspx>

23 The European Court of Human Rights, for example, can hear complaints by individuals of violations of the ECHR (n 10). The African Court on Human and Peoples' Rights was established by African countries. It is intended to complement the functions of the African Commission on Human and Peoples' Rights. By way of further example, the Inter-American Human Rights Commission is a quasi-judicial body established by the Charter of the Organisation of American States and the American Convention on Human Rights. 
contrast, the rights contained in ICESCR are perceived to pose positive obligations, albeit in some circumstances on a 'best efforts' basis. For example, ICESCR includes the right to work, to enjoyment of just and favourable conditions of work, the right of all peoples to freely dispose of their natural wealth and resources, the right to an adequate standard of living, including adequate food, clothing and housing, the highest attainable standard of physical and mental health, the right to education, the right to take part in cultural life; and the right to enjoy the benefits of scientific progress and its applications.

\section{iii. Individuals as the subject of human rights law}

Unlike many other areas of international law, international human rights law, along with international criminal law, recognises individual persons as the subject of rights and duties (as distinct from only nation states being the subject of rights and duties to one another which is by far the most typical case in other areas of international law). This means that individuals in outer space may both owe (such as the obligation to not persecute or discriminate on the basis of gender, race, religion, etc) and be owed human rights obligations (such as the right to health, fair trial rights, access to education and the benefits of scientific knowledge, and so forth).

\section{iv. Extraterritorial human rights obligations}

While jurisdiction (in this context, meaning the extent of public authority over conduct) is primarily territorial, customary international law recognises a number of bases on which the state may have legal authority to act extraterritorially, including the nationality principle, the universality principle, the effects doctrine and protective principle of jurisdiction. ${ }^{24}$ Some contemporary commentary on these principles suggests they are outdated, particularly in the context of cyber space ${ }^{25}$ and increased human activity in outer space. However, setting that claim aside for now, in terms of extraterritorial legal obligations (as opposed to extraterritorial legal authority), the traditional starting point for human rights and jurisdiction has been that:

A state is not responsible under human rights law for every act or omission by any person that arises within its jurisdiction. However, a state's responsibility under human rights law is limited by its jurisdiction. That is, a state cannot be responsible for acts or omissions under human rights law that fall outside its jurisdiction. ${ }^{26}$

Notwithstanding that, all major international human rights courts and tribunals have tended to accept that extraterritorial human rights obligations arise 'when a state has

24 For further and detailed discussion of the principles of jurisdiction at international law, see for example Danielle Ireland-Piper, 'Recapping Extraterritorial Jurisdiction' in Extraterritoriality in East Asia: Extraterritorial Criminal Jurisdiction in China, Japan, and South Korea (Edward Elgar 2021); Danielle Ireland-Piper, Accountability in Extraterritoriality: An International and Comparative Law Perspective (Edward Elgar, 2017); Danielle Ireland-Piper, 'Prosecutions of extraterritorial criminal conduct and the abuse of rights doctrine' (2013) 9 Utrecht Law Review 68; Danielle Ireland-Piper, 'Extraterritorial Criminal Jurisdiction: Does the Long Arm of the Law Undermine the Rule of Law?' (2012) 13 Melbourne Journal of International Law 122.

25 See for example Dan Jerker B. Svantesson, 'A new legal framework for the age of cloud computing' (The Conversation, 3 February 2015) <http://theconversation.com/a-new-legal-framework-for-the-age-ofcloud-computing-37055>; Dan Jerker B Svantesson, 'Internet \& Jurisdiction Global Status Report 2019', (Secretariat of the Internet \& Jurisdiction Policy Network 2019) 28.

26 Sarah Joseph and Sam Dipnell, 'Scope of application' in Daniel Moeckli, Sangeeta Shah, and Sandesh Sivakumaran (eds) International Human Rights Law (Oxford University Press 2018) 151; see, generally, UNGA Res 56/83 (12 December 2001) $53^{\text {rd }}$ Session, annex. 
effective control of a foreign territory, and when it exercises control over the person whose rights have been allegedly abused' ${ }^{27}$ Further, there is merit to the argument that the 'the concept of jurisdiction in human rights law should be distinguished from that found in general international law' ${ }^{28}$ This is because each has two different objectives: the purpose of jurisdiction in general international law being to delineate spheres of state sovereignty; whereas in human rights law, the purpose of jurisdiction is to define to the applicability of human rights law and to assess state responsibility. ${ }^{29}$ In human rights law, jurisdiction is not necessarily territorial, but established by effective control over territory or persons even outside states' territories.

The jurisdictional clauses of the International Covenant on Civil and Political Rights provide that State Parties shall respect, ensure, or secure to everyone within their "jurisdiction" the rights recognized by the Convention. ${ }^{30}$ In its advisory opinion, Legal Consequences of the Construction of a Wall in the Occupied Palestinian Territory, ${ }^{31}$ the International Court of Justice held that States parties to the International Covenant on Civil and Political Rights should be bound to comply with its provisions, even when exercising jurisdiction outside national territory. ${ }^{32}$ The Inter-American Court of Human Rights also considered the extraterritorial application of human rights law in the specific context of transboundary environmental harm. ${ }^{33}$ The Court observed:

[...] the exercise of jurisdiction by a State of origin is based on the understanding that it is the State in whose territory or under whose jurisdiction the activities were carried out that has the effective control over them and is in a position to prevent them from causing transboundary harm that impacts the enjoyment of human rights of persons outside its territory. ${ }^{34}$

Further, as Seunghwan Kim has suggested, 'the concept of state sovereignty has begun to undergo a paradigm shift that places extraterritorial human rights concerns ... squarely within a legal rather than merely a moral framework' ${ }^{35}$ While writing about the specific context of the principle of non-refoulement and external migration, the point has relevance across a range of human rights obligations. However, there still exists in many countries an accountability gap in regulating extraterritorial action of the State. Domestic courts not subject to regional courts like the European Court of Human Rights may lack the legal basis and/or will to hold the State accountable for extraterritorial action. For example,

27 Joseph and Dipnell (n 26) 158.

28 Seunghwan Kim, 'Non-Refoulment and Extraterritorial Jurisdiction: State Sovereignty and Migration Controls at Sea in the European Context' (2017) 30 Leiden Journal of International Law 49, 51.

29 Anna Klug and Tim Howe, 'The Concept of State Jurisdiction and the Applicability of the Nonrefoulement Principle to Extraterritorial Interception Measures' in Bernad Ryan and Valsamis Mitsilegas (eds) Extraterritorial Immigration Control: Legal Challenges (Brill 2010) 98.

30 ICCPR (n 9) art 2(1); See, for example, UNHRC 'General Comment 31: The Nature of the General Legal Obligation Imposed on States Parties to the Covenant' (2004) UN Doc CCPR/C/21/Rev.1/Add.13 paras 8, 15, 18.

31 Wall Opinion (n 1).

32 ibid 109. See also (n 2).

33 Inter-American Court of Human Rights The Environment and Human Rights (Advisory Opinion) (2017) OC-23/17.

34 ibid 102.

$35 \operatorname{Kim}($ n 28) 49. 
courts in Canada and the United States have found that domestic constitutional protections may not apply extraterritorially. ${ }^{36}$

A decision of the High Court of Australia, Plaintiff M68/2015 v Minister for Immigration and Border Protection, also illustrates a different sort of accountability gap wherein the extraterritorial involvement of Australian in offshore detention in Nauru was held not to be justiciable by an Australian Court due to the sovereign status of Nauru as a nation state ${ }^{37}$ In essence, this overlooks the capacity for collective and ancillary responsibility at international law, particularly as relates to principles of state responsibility for internationally wrongful acts. ${ }^{38}$

In any event, however, an obvious interpretive issue for current purposes is whether human rights treaties extend extraterritorially into outer space, especially in light of the existence of a lex specialis group of space treaties. We suggest that they do, given international human rights law is a part of international law generally, and it is generally accepted (dissenters aside) that international law applies in outer space. ${ }^{39}$ In our view, and given the undoubted increased frequency and extent of human presence in space now and into the future, it would seem counter-intuitive to argue that the principles that are to guide the rights of humans on Earth would not also guide the rights of human in space.

Having briefly introduced the foundations of international human rights law, we now recap space law.

\section{B. Recapping Space Law}

For the most part, space law has historically comprised mainly international law. There are currently five key international treaties specifically governing space: the "Outer Space Treaty" " ; the "Rescue Agreement"41; the "Liability Convention"42; the "Registration Convention"43; and the "Moon Agreement". ${ }^{44}$ In essence, the Outer Space Treaty, as a binding instrument, is also an exhortation to good behaviour: the exploration and use of outer space is to be free, in the interests of all countries, and not subject to a claim of national sovereignty. The Moon and other celestial bodies are to be used only for peaceful purposes. States are prohibited from placing weapons of mass destruction in Earth orbit or outer space and the militarization of celestial bodies is forbidden. States are internationally responsible for national space activities and internationally liable for damage caused by their space objects.

The Rescue Agreement requires States to take all possible steps to rescue and assist astronauts in distress and promptly return them to the launching authority, and to provide

36 See $R v$ Hape [2007] SCC 26; $R v$ Klassen [2008] BCSC 1762; Frederick Ker $v$ Peoples of the State of Illinois 119 US 436 (1886).

37 Plaintiff M68/2015 v Minister for Immigration and Border Protection (2016) 257 CLR 42 (M68).

38 For an extended discussion of this point, see Danielle Ireland-Piper, 'Outdated and Unhelpful: The Problem with the Comity Principle and Act of State Doctrine' (2018) 24 Australian International Law Journal 15.

39 See Outer Space Treaty (n 6) art III which provides inter alia that 'activities in the exploration and use of outer space' are to be carried out 'in accordance with international law ...'.

40 ibid.

41 Agreement on the Rescue of Astronauts, the Return of Astronauts and the Return of Objects Launched into Outer Space (adopted 22 April 1968, entered into force 3 December 1969) 672 UNTS 119 (Rescue Agreement).

42 Convention on International Liability for Damage Caused by Space Objects (adopted 29 March 1972, entered into force 1 September 1972) 961 UNTS 187 (Liability Convention).

43 Convention on Registration on Objects Launched into Outer Space (adopted 14 January 1975, entered into force 15 September 1976) 1023 UNTS 15 (Registration Convention).

44 Moon Agreement (n 13). 
assistance to launching States in recovering space objects that return to Earth outside their territory. Under the Liability Convention, which also provides for procedures for the settlement of claims for damages, a launching State is, depending on the circumstances, potentially liable to pay compensation for damage caused by its space objects.

The Registration Convention requires States, and some intergovernmental organizations, to establish national registries and provide information on their space objects to the UN Secretary-General. According to the United Nations Office for Outer Space Affairs, as at June 2020, approximately $86 \%$ of all satellites, probes, landers, crewed spacecraft and space station flight elements launched into Earth orbit or beyond have been registered, ${ }^{45}$ However, the launch of large constellations of smaller satellites and the trend towards miniaturization may put some considerable pressure on the compliance rate in the future. ${ }^{46}$ Registration also occurs voluntarily in accordance with UN General Assembly Resolution 1721B and is still actively being undertaken by States that are not party to the Registration Convention.

The Moon Agreement reaffirms and elaborates on many of the provisions of the Outer Space Treaty relating to the Moon and other celestial bodies: such as the use of celestial bodies being exclusively for peaceful purposes, and the Moon and its natural resources being the 'common heritage of [hu]mankind'. It also calls on States parties to that instrument to establish an international regime to govern the exploitation of resources when such exploitation is about to become feasible.

The International Space Station Intergovernmental Agreement (IGA) is also important in the context of criminal jurisdiction. The IGA is an international agreement signed on 29 January 1998 by governments and the European Space Agency involved in the Space Station project. Although drafted not a general treaty in the traditional sense (due largely to US domestic concerns), the IGA is a rare 'positive source of criminal law' ${ }^{47}$ in outer space. The implications of this will be considered in the section on jurisdiction in Part III below.

In addition to the five space treaties, there are also five key declarations and principles relating to space: the "Declaration of Legal Principles"48; the "Broadcasting Principles"49; the "Remote Sensing Principles" 50; the "Nuclear Power Source Principles" the "Benefits Declaration". ${ }^{2}$ We will not detail these but mention them for completeness.

In short, aside from general principles relating to the exploration and use of outer space, there are no specific binding instruments relating to individual human rights in space, although there is clear recognition in the binding instruments of the need to be cognizant and take account of the 'interests and needs of the developing countries' ${ }^{53}$ Some

45 United Nations Office for Outer Space Affairs, 'United Nations Register of Objects Launched into Outer Space, (United Nations Office for outer Space Affairs, 25 June 2020) $<$ http://www.unoosa.org/oosa/en/spaceobjectregister/index.html>

46 See generally Steven Freeland, 'Newspace, small satellites, and law: finding a balance between innovation, a changing space paradigm, and regulatory control' in $\mathrm{Md}$ Tanveer Ahmad and Jinyuan Su (eds) NewSpace Commercialization and the Law (McGill University 2017) 107.

47 PJ Blount, 'Jurisdiction in Outer Space: Challenges of Private Individuals in Space' (2007) 33 Journal of Space Law 300, 312-313.

48 UNGA Res 1962 (XVII) (13 December 1963) GAOR $18^{\text {th }}$ Session Supp 15.

49 Broadcasting Principles (n 14).

50 Remote Sensing Principles (n 14).

51 Principles to Use of Nuclear Power Sources in Outer Space (n 14).

52 Use of Outer Space for Benefit and Interest of All States (n 14).

53 See for example Moon Agreement (n 13) art 11(7)(d). 
of the space declarations do make reference to specific human rights ${ }^{54}$ although, as noted, these are not expressed in instruments that are per se binding. However, in recent times, there has been significant growth in national space law, which both complements and supplements the rights and obligations that arise under the relevant treaty law. Examples of specific activities in and/or relating to outer space, and the potential implications for human rights and human rights law, are now considered.

\section{Human activities in Outer Space: Implication for Human Rights}

The first two issues we consider relating to human activity in outer space are that of access to space and the related issue of remote-sensing and artificial intelligence technologies. This gives cause to consider rights, such as the 'right to enjoy the benefits of scientific progress and its applications' (REBSP) as enshrined in ICESCR, and the right to privacy, on the one hand; and the right to other life-sustaining services, on the other.

\section{A. Access to Space and Remote Sensing and Artificial Intelligence (AI) Technologies}

Human access to outer space has increased and this trend will undoubtedly continue. While 'technology has evolved and ... the range of activities planned for outer space has proliferated' ${ }^{55}$ this does not necessarily represent an equality of access. At present, of the 195 Member States of the United Nations, approximately 70-80 are engaged in space activities and thus involved in domestic capability development to allow them to participate actively in directly accessing space. Of course, viewed from another perspective, this also means that somewhere approaching two-thirds of the world's countries do not have any indigenous space capability whatsoever, placing them at an increasing comparative disadvantage over time and rendering them entirely dependent on others for access to space infrastructure and, indeed, access to space itself.

Obviously, this gives rise to sovereignty and national security concerns for those States. Their ability therefore to access space and enjoy the benefits that this will bring in terms of their development and the development and livelihood of those under their jurisdiction is thus severely curtailed and highly dependent on the swings and roundabouts of strategic and geopolitical networks and understandings. The issue of access to outer space and the associated ensuing benefits is linked with the right to enjoy the benefits of scientific progress and its applications (REBSP), as enshrined in Article 27 of the UDHR, which stipulates that 'everyone has the right... to share in scientific advancements and its benefits'; and in Article 15 of the ICESCR, which recognises 'the right of everyone to enjoy the benefits of scientific progress and its applications.'

In turn, this right is 'especially connected' ${ }^{56}$ to other rights including, but not limited to, the right to education (in Article 13 and 14 of the ICESCR, for example), the right to seek, receive, and impart information (in Article 19 of the UDHR, for example) and the right to development, such as is recognised in the United Nations Declaration on the Right to Development ${ }^{57}$ for example. The connection between these rights and human activity in

\footnotetext{
54 See for example Broadcasting Principles (n 14) principle A.

55 Steven Freeland, 'Up, up and ... Back: The Emergence of Space Tourism and Its Impact on the International Law of Outer Space' (2005) 6 Chicago Journal of International Law 1, 5.

56 United Nations Educational, Scientific and Cultural Organisation, 'The Right to Enjoy the Benefits of Scientific Progress and its Applications' (Experts' Meeting on Scientific Progress, Venice, July 2009$) 5$.

57 UNGA Res 41/128 (4 December 1986) UN Doc A/RES/41/128.
} 
space is particularly pronounced given the humanitarian applications of space technologies and access, particularly remote-sensing activities.

Further, in a general sense, the REBSP 'is important to redress the negative effects of globalization and to eradicate poverty'. ${ }^{58}$

It is also true, however, that 'individuals should be protected from possible negative effects of scientific and technological progress on the enjoyment of human rights'. ${ }^{59}$ One particular way in which these competing interests arise is in the capability to access space for the purpose of remote sensing. Remote sensing is conducted via satellites and aircraft that detect and record imagery. ${ }^{60}$ Some satellite images are commercially available, with such images 'becoming sharper and taken more frequently'. ${ }^{61}$ In 2008, there were 150 Earth observation satellites in orbit; by June 2019, there were $768 .{ }^{62}$ These numbers are set to increase even more dramatically with the advent of proposed large constellations of small Earth observation satellites. The term "remote sensing of the Earth from outer space" was defined in the 1979 Convention on the Transfer and Use of Data of Remote Sensing of the Earth from Outer Space as:

observations and measurements of energy and polarization characteristics of selfradiation and reflected radiation of elements of the land, ocean and atmosphere of the Earth in different ranges of electromagnetic waves which facilitate the location, description of the nature and temporal variations of natural parameters and phenomena, natural resources of the Earth, the environment as well as anthropogenic objects and formations. ${ }^{63}$

In turn, the Principles relating to Remote Sensing of the Earth from Outer Space describe remote sensing as:

making use of the properties of electromagnetic waves emitted, reflected or diffracted by the sensed objects, for the purpose of improving natural resources management, land use and the protection of the environment. ${ }^{64}$

As noted at the outset of this article, remote-sensing technologies have humanitarian applications. Remote-sensing technologies can assist in promoting, for example, the right to education (recognised in Article 26 of the $U D H R$, as well as in other international treaties) through facilitating remote access learning and advances in scientific knowledge; and even, given the broad agricultural applications of these technologies, the right to food (as recognised in Article 2 of ICESCR, and further articulated in General Comment No. 12) and the right to safety (from, for example, natural disasters). Incidentally, the right to food is a significant right because it is 'indivisibly linked to the inherent dignity of the

58 Experts' Meeting on Scientific Progress (n 56) 4.

59 ibid 6.

60 'What is Remote Sensing', (Earthdata, 10 March 2021) <https://earthdata.nasa.gov/learn/remotesensing>

61 Christopher Beam, 'Soon, satellites will be able to watch you everywhere all the time: Can privacy survive?' (MIT $\quad$ Technology $\quad$ Review, $26 \quad$ June 2019 ) <https://www.technologyreview.com/2019/06/26/102931/satellites-threaten-privacy/>

62 ibid.

63 Convention on the Transfer and Use of Date of Remote Sensing of the Earth from Outer Space (adopted 19 May 1978, entered into force 21 August 1979) (Moscow Convention).

64 Remote Sensing Principles (n 14) principle I. 
human person and is indispensable for the fulfilment of other human rights' ${ }^{65}$ It is also 'inseparable from social justice'. ${ }^{66}$

However, such technologies (and the data collected) also can be used to achieve national security objectives, some of which will be consistent with human rights objectives; but others less so. For example, in the United States, the U.S. Commercial Space Launch Competitiveness Act refers to 'the need to protect national security while maintaining United States private sector leadership in the field, and reflect the current state of the art of remote sensing systems, instruments, or technologies. ${ }^{67}$ The reality is that there will at some point always be a tension between aspects around the need to protect national security on the one hand and the full gamut of available human rights to the populous on the other.

While the full implication of this in the space context is yet to be appropriately considered, recognition of the link between remote sensing and various human rights issues is evident in, for example, UN Resolution 41/65, Principles Relating to Remote Sensing of the Earth from Outer Space. ${ }^{68}$ This mirrors sentiments expressed in Article I of the Outer Space Treaty, and provides that remote-sensing 'shall be carried out for the benefit and in the interests of all countries', and also taking 'into particular consideration the needs of the developing countries'. ${ }^{6}$ Principle III calls for compliance with international law. Principles X and XI provide, for example, that remote sensing should help protect the natural environment on Earth and humans from natural disasters.

Notably, remote-sensing technologies also have consequences for the capacity of criminal justice systems to redress human rights violations. As Steven Freeland and Ram Jakhu have observed in the specific context of international criminal justice: 'Satellite imagery is proving to be a valuable tool for the collection and presentation of critical, accurate, timely and credible evidence before courts/tribunals' ${ }^{70}$ However, those authors go on to note that 'challenges still need to be met in the development of appropriate satellite imaging and other technologies as well as relevant procedural matters related to the use of evidence acquired with the use of satellites' ${ }^{71}$

Of course, the capacity to utilize remote sensing data in criminal justice also comes with consequences for the right to privacy more generally (such as recognised in Article 12 of the $U D H R$ and Article 17 of the ICCPR, among others). As privacy advocates have warned:

innovation in satellite imagery is outpacing the ... government's ability to regulate the technology. Unless we impose stricter limits now ... one day everyone from ad companies to suspicious spouses to terrorist organisations will have access to tools previously reserved for government spy agencies. Which would mean that at any given moment, anyone could be watching anyone else'. ${ }^{72}$

This is significant because, as NGO Privacy International has recognised: 'privacy give us the ability to assert our rights in the face of significant power imbalances' and 'is an

65 CESCR, 'General Comment No 12: The Right to Adequate Food (Art. 11)' (1999) UN Doc E/C.12/1999/5.

66 ibid.

672 USC $\S 202$ (U.S. Commercial Space Launch Competitiveness Act).

68 Remote Sensing Principles (n 14).

69 ibid principle II.

70 Freeland and Jakhu (n 5) 31.

71 ibid.

72 Beam (n 61). 
essential way we seek to protect ourselves ... from others who may wish to exert control' ${ }^{73}$ Thus, there is tension between knowledge and information and humanitarian causes on the one hand, and privacy rights on the other.

In this context, one should also consider that AI technology is an increasingly important element of space technology. Various aspects of AI potentially seem well suited to a number of current and proposed space applications, including the following:

(i) Remote sensing and monitoring for a broad array of missions, including environmental change, national security and aircraft and maritime tracking;

(ii) Communications between ground and space, and from satellite-to-satellite (particularly in the case of mega/large constellations of small satellites), using radio frequencies, optical-laser communications, radar and other technologies;

(iii) Data analytics, including policy and regulatory issues inherent in collecting massive amounts of information, and how that information can be used, as well as data privacy;

(iv) Satellites as an alternative to terrestrial-based systems, including cloud computing, cross-border broadband services, and other methods of data and information transfer.

Simply put, the implementation of AI impacts upon privacy issues, but also the full range of human rights guaranteed by international human rights instruments, including civil and political rights, as well as economic, cultural, and social rights. The need to address these concerns - and not simply be 'seduced' by the increased capabilities that AI might offer in terms of space activities - is highlighted even further by the fact that space has become a significant global 'economy' ${ }^{74}$ with a multitude of private and commercial activities engaging in myriad space activities, each directed towards profitability without, one might speculate, sufficient thought being given to the (potential) human rights consequences. ${ }^{75}$ We now move to consider the issues of space debris and space mining. Each of these activities raise human rights issues relating to access, safety, and the emerging right to a safe environment.

\section{B. Space Debris}

Space debris - sometimes referred to as 'space junk' ${ }^{76}$ - and the cascading effects represent one of the greatest challenges for the long-term sustainability of space activities. According to estimates, as of January 2019, there were in Earth orbit more than 128 million pieces of

\section{3 'What is Privacy' (Privacy International, $23 \quad$ October 2017 )} $<$ https://privacyinternational.org/explainer/56/what-privacy>

74 The global space economy in 2020 has transitioned toward the private sector, with a decreased reliance on government spending; '30 Voices on 2030: The future of space' (KPMG, 2020) $<$ https://assets.kpmg/content/dam/kpmg/au/pdf/2020/30-voices-on-2030-future-of-space.pdf>; The COVID-19 pandemic did not significantly impact the space sector with increase in the European space workforce and similar trends of successful launched, with growth of \$9 billion USD reported, increasing the overall global space economy to $\$ 423.8$ billion USD; 'Global Space Economy Grows in 2019 to \$423.8 Billion, The Space Report 2020 Q2 Analysis Shows' (Space Foundation, 30 July 2020) $<$ https://www.spacefoundation.org/2020/07/30/global-space-economy-grows-in-2019-to-423-8billion-the-space-report-2020-q2-analysis-shows/>

75 For a detailed discussion, see Anne-Sophie Martin and Steven Freeland, 'The Advent of Artificial Intelligence in Space Activities: New Legal Challenges' (2021) 55 Space Policy 101408.

76 Mark Garcia, 'Space Debris and Human Spacecraft' (National Aeronautics and Space Administration Space Station, 7 August 2017) <https://www.nasa.gov/mission_pages/station/news/orbital_debris.html> 
debris smaller than $1 \mathrm{~cm}$, about 900,000 pieces of debris $1-10 \mathrm{~cm}$ in length, and around 34,000 pieces larger than $10 \mathrm{~cm}$. Space debris is typically comprised of orbital debris and natural debris. ${ }^{77}$ Space debris principally comprises those space objects (satellites) that have reached their end of life, various launch stages (for example, rocket bodies, upper stages of launch vehicles) and the remnants of space objects from explosions, conjunctions or deliberate destruction, but will also include other items that are deliberately or accidentally released during a space mission. It can be decomposed into natural (meteoroid) and artificial (human-made) particles in space. Human-made debris has also been defined as 'any piece of machinery or debris left by humans in space'. ${ }^{78}$

Generally, meteoroids - defined as 'a small chunk of rock or iron that travels through space $^{79}$ - orbit around the sun, while human-made debris tends to orbit around Earth. Consequently, the latter is classified as 'orbital debris' ${ }^{80}$ defined as 'any [hu]man-made object in orbit about the Earth which no longer serves a useful function'. ${ }^{81}$

If a piece of debris that causes damage can be definitively identified, it may also constitute a 'space object' within the terms of the liability for damage regime under international space law. ${ }^{82}$ The Inter-Agency Space Debris Co-ordination Committee ('IADC') has described orbital debris as 'all [hu]man-made objects, including fragments and elements thereof, that are orbiting the Earth or re-entering the Earth's atmosphere, that are non-functional'. ${ }^{83}$ The United Nations Technical Report on Space Debris ('UNTRSD') describes orbital debris in similar terms. ${ }^{84}$ The following incident reported in Nature, $a$ science magazine, illustrates part of the problem:

On Monday 2 July 2018, the CryoSat-2 spacecraft was orbiting as usual, just over 700 kilometres above Earth's surface. But that day, mission controllers at the European Space Agency (ESA) realized they had a problem: a piece of space debris was hurtling uncontrollably towards the $€ 140$ million (US\$162 million) satellite, which monitors ice on the planet.

As engineers tracked the paths of both objects, the chances of a collision slowly increased - forcing mission controllers to take action. On 9 July, ESA fired the thrusters on CryoSat- 2 to boost it into a higher orbit. Just 50 minutes later, the debris rocketed past at 4.1 kilometres a second. ${ }^{85}$

Debris orbits at speeds up to $17,500 \mathrm{mph}(28,154 \mathrm{~km} / \mathrm{hr})$. At such velocities, debris may cause damage to spacecraft. For example: in 1996, a French satellite was damaged by debris from a French rocket which exploded a decade before ${ }^{86}$ in 2007 , China executed

77 ibid.

78 Jonathan O'Callaghan, 'What is space junk and why is it a problem?', (Natural History Museum) $<$ https://www.nhm.ac.uk/discover/what-is-space-junk-and-why-is-it-a-problem.html>

79 Sandra May, 'Meteoroid' (National Aeronautics and Space Administration, 7 August 2017) <https://www.nasa.gov/audience/forstudents/k-4/dictionary/Meteoroid.html>

80 Garcia (n 76).

81 ibid.

82 Liability Convention (n 42).

83 Space Debris Team Project, 'Space Debris' (International Space University 2012) 1.

84 ibid, citing UN COPUOS (Sub-Committee), 'United Nations Technical Report on Space Debris' (1999) UN Doc A/AC.105/720 (Technical Report on Space Debris) 11.

85 Alexandra Witze, 'The quest to conquer Earth's space junk problem' (2018) 561 Nature 24, 25.

86 'Does Space Junk Fall from the Sky?' (National Oceanic and Atmospheric Administration, 19 January 2018) $<$ https://www.nesdis.noaa.gov/content/does-space-junk-fall-sky> 
an anti-satellite test destroying an old weather satellite using a missile, allegedly adding more than 3,000 pieces of orbital debris; ${ }^{87}$ and in 2009 , a defunct Russian satellite collided with a functioning US Iridium satellite, adding over 2,000 pieces of trackable debris. ${ }^{88}$

Not only does this pose safety concerns; the increasing proliferation of space debris may develop into a barrier to accessing space, and therefore, reduce access some of the benefits to human rights of such access. Efforts to address the issue of mitigation guidelines include the IADC Space Debris Mitigation Guidelines, ${ }^{89}$ and the United Nations Space Debris Mitigation Guidelines of the Committee on the Peaceful Uses of Outer Space (UN Space Debris Guidelines), adopted by the full United Nations General Assembly in late 2007. ${ }^{90}$ Regional organisations, including the European Space Agency ('ESA'), ${ }^{91}$ and domestic space agencies, including in China, ${ }^{92}$ France, ${ }^{93}$ Germany, ${ }^{94}$ Italy, ${ }^{95}$ Japan, ${ }^{96}$ the United Kingdom, ${ }^{97}$ the United States,${ }^{98}$ and Russia ${ }^{99}$ have also developed guidelines. ${ }^{100}$ NASA has developed programs such as LEGEND and ORDEM 3.0 to predict future debris environment. ${ }^{101}$ There have been, for example, discussions around utilising nets and harpoons to capture debris, and tethers, drag augmentation devices and solar sails to remove debris. ${ }^{102}$ Further, the importance of developing appropriate practices with respect to orbital space debris has more recently (June 2019) been further highlighted by the

87 See also Becky Iannotta, 'U.S. Satellite Destroyed in Space Collision' (Space News, 11 February 2009) $<$ https://spacenews.com/u-s-satellite-destroyed-in-space-collision/>

88 Garcia (n 76).

89 Inter-Agency Space Debris Coordination Committee, 'IADC Space Debris Mitigation Guidelines' (2007) <https://orbitaldebris.jsc.nasa.gov/library/iadc_mitigation_guidelines_rev_1_sep07.pdf>

90 UNGA Res 62/217 (1 February 2008) UN Doc A/RES/62/217.

91 Committee on the Peaceful Uses of Outer Space, 'Space Debris Mitigation Handbook' (1999); Committee on the Peaceful Uses of Outer Space, 'Space Debris Safety and Mitigation Standard' (2000).

92 Commission for Science, Technology and Industry for National Defence, 'Requirements for Space Debris Mitigation' (2005) Document QJ3221-2005.

93 Loi n 2008-518 du 3 juin 2008; Décret nº 2009-643 du 9 juin 2009.

94 European Space Agency, 'European Code of Conduct for Space Debris Mitigation' (2004) Document No 1 (ECCSDM).

95 ibid.

96 Japan Aerospace Exploration Agency, 'Space Debris Mitigation Standard' (2014) (Document JMR003C).

97 ECCSDM (n 94); Outer Space Act 1986 (UK).

98 See for example United States Government Orbital Debris Mitigation Standard Practices, FCC-02-80 (2002); National Aeronautics and Space Administration, 'NASA Procedural Requirements for Limiting Orbital Debris and Evaluating the Meteoroid and Orbital Debris Environments' (2017) Document NPR 8715.6B.

99 Federal Law of August 201993 No. 5663-I (Russia); Federal Law of July 132015 No. 215-FZ (Russia); Federal Law of June 292015 No. 162-FZ (Russia); Order of the Federal Agency for Technical Regulation and Metrology, Space Technology Items: General Requirements for Space Vehicles for Near-Earth Space Debris Mitigation (Document, GOST R 52925-2018, 21 September 2018). See also Federal Space Program of Russia for 2016-2025 (approved by the Russian Federation Government Decree of 23 March 2016 N 230); Fundamentals of the Russian Federation's State Policy in the Field of Space Activities for the Period up to 2030 and Beyond (approved by the President of the Russian Federation on April 19, 2013 N Pr906).

${ }^{100}$ National Aeronautics and Space Administration , 'Orbital Debris Management and Risk Mitigation' (2012) 23.

101 ibid 5 .

${ }^{102}$ National Research Council, 'Limiting Future Collision Risk to Spacecraft - An Assessment of NASA's Meteoroid and Orbital Debris Programs' (The National Academies Press 2011) 59. 
adoption within UNCOPUOS of the Preamble and 21 Guidelines for the Long-Term Sustainability of Outer Space Activities. ${ }^{103}$

Notwithstanding that, the issue of space debris poses obvious threats of property damage, safety, and potentially, the right to life in the case of severe collisions. Congestion and ensuing safety risks also potentially have implications for equality of access to space (and therefore the knowledge and information rights discussed above). There are also likely risks to the natural environment. In the same way that plastics pose risks to the marine environment and therefore, to any ensuing human rights enjoyments, this may also prove to be true of debris in our atmosphere. In more general terms, the avoidance of a 'tragedy of the commons' scenario ${ }^{104}$ is crucial if humankind is to garner the maximum benefit from what space can offer.

\section{Space Mining}

The Solar System is replete with resources such as the water, minerals, precious metals found on moons and asteroids. This has attracted interest from both scientists and entrepreneurs. Not only is this (potentially) of enormous financial value if transported back to Earth, but may also assist in onward space travel, and the building of future settlements and outposts. Technological equipment required for space mining, however, is still very much in its development phases. ${ }^{105}$ Nonetheless, in 2019, a collection of rock samples was taken from the asteroid Ryugu by Japanese spacecraft Hayabusa-2. ${ }^{106}$

Luxemburg, the United Arab Emirates (UAE), and the United States, for example, have indicated through their domestic laws an intention to facilitate and regulate space mining. Luxembourg passed legislation in 2017 'granting businesses operating within its jurisdiction rights in resources extracted in outer space'. ${ }^{107}$ That legislation asserts 'space resources are capable of being appropriated in accordance with international law'. ${ }^{108}$ In the UAE, Federal Law No. (12) of 2019 on the Regulation of The Space Sector, ${ }^{109}$ expressly

${ }^{103}$ UNGA 'Report of the Committee on the Peaceful Uses of Outer Space' UN GAOR $74^{\text {th }}$ session Supp No 20 UN Doc A/74/20 (2019) (Report of the Committee on the Peaceful Uses of Outer Space) para 163; UNGA 'Report of the Committee on the Peaceful Uses of Outer Space' UN GAOR $74^{\text {th }}$ session Supp No 20 UN Doc A/74/20 (2019) (Guidelines for the Long-term Sustainability of Outer Space Activities of the Committee on the Peaceful Uses of Outer Space) annex II.

104 See Garrett Hardin, 'The tragedy of the commons' (1968) 162 Science 1243. For a discussion of the implications of the tragedy of the commons to the use of outer space, see Steven Freeland, 'Common heritage, not common law: how international law will regulate proposals to exploit space resources' (2017) 35 Questions of International Law 19.

105 Virginie Blanchette-Seguin, 'Reaching for the Moon: Mining in Outer Space' (2017) 49 New York University Journal of International Law and Politics 959, 969.

106 This sample collection occurred approximately 300 million kilometres from Earth, with the return taking place at Woomera, Australia in December 2020. See Steven Freeland and Annie Handmer, 'Giant leap for corporations? The Trump administration wants to mine resources in space, but is it legal?' (The Conversation, 20 April 2020) <https://theconversation.com/giant-leap-for-corporations-the-trumpadministration-wants-to-mine-resources-in-space-but-is-it-legal-136395>

${ }^{107}$ Loi du 20 juillet 2017 sur l'exploration et l'utilisation des ressources de l'espace [Law of 20 July 2017 on the exploration and use of space resources] (Luxembourg) art 1 [tr Vincent Wellens] (Luxembourg Space Law). See also the discussion of Luxembourg's contentious space mining laws as compared with art II of the Outer Space Treaty (n 6) in Philip De Man, 'Luxembourg law on space resources rests on contentious relationship with international framework' (2017) Working Paper No 189, 5.

108 Stefan A Kaiser, 'Legal Protection against Contamination from Space Resource Mining' (2017) 66 German Journal of Air and Space Law 282, 284 citing Luxembourg Space Law (n 107).

109 Federal Law No. (12) of 2019 on the Regulation of The Space Sector (United Arab Emirates) 19 December 2019, Corresponding to 22 Rabi' Al-Akhar 1441H [Federal Law No. 12 of 2019] (UAE Law). See also Kelsey Warner, 'UAE looks to regulate asteroid mining as it aims to lure private space sector' (The National, 26 November 2019) <https://www.thenational.ae/uae/science/uae-looks-to-regulate- 
contemplates permits for the exploration, exploitation and use of Space Resources. ${ }^{110}$ In 2015, the US adopted the US Commercial Space Launch Competitiveness Act (H.R.2262) ${ }^{111}$ to facilitate 'commercial exploration for and commercial recovery of space resources by United States citizens'. ${ }^{112}$

More recently, NASA has released the principles that it proposes to govern the 'Artemis Accords' that it will seek to negotiate on a bilateral basis with partners in its Artemis Moon / Mars endeavours. ${ }^{113}$ Although the details of these accords are yet to be finalised, these overarching principles appear to be highly relevant regarding any proposed future activities involving exploitation of space natural resources and their ensuing impact on the enjoyment of human rights and on human rights law. Both the US and Luxembourg have expressly acknowledged the terms of Article II of the Outer Space Treaty, which specifies that that outer space, including the Moon and other celestial body, 'is not subject to national appropriation by claim of sovereignty, by means of use or occupation, or by any other means'. ${ }^{114}$

However, some commentators suggest that the US approach distinguishes the term 'resources' from the term 'celestial bodies' used in Article II of the Outer Space Treaty. ${ }^{115}$ The US legislation prevents classification of spatial resources as a 'celestial body' and so rights are granted to the minerals in the celestial body, not the body itself. ${ }^{116}$ Essentially, according to this viewpoint, the US position is that the lawfulness of mining "resources" in the celestial body, rather than appropriating the celestial body itself, fills a lacunae in the Outer Space Treaty. ${ }^{117}$ On this view, the 'use, ownership, possession and sale of mineral resources do not constitute a (national) appropriation by means of use or by any other

asteroid-mining-as-it-aims-to-lure-private-space-sector-1.943028>; Sam Bridge 'New UAE Space Law to open doors to foreign investment' (Arabian Business Industries, 28 February 2020) $<$ https://www.arabianbusiness.com/technology/441175-new-uae-space-law-to-open-doors-to-foreigninvestment>.

110 UAE Law (n 109) art 18.

111 U.S. Commercial Space Launch Competitiveness Act (n 67).

112 Interview with Steven Freeland, Professor of International Law at Western Sydney University (April 2020) (Steven Freeland Interview) referring to U.S. Commercial Space Launch Competitiveness Act (n 67); Freeland and Handmer (n 106) citing U.S. Commercial Space Launch Competitiveness Act (n 67); Stephan Hobe, 'The International Institute of Space Law adopts Position Paper on Space Resource Mining' (2016) 65 German Journal of Air and Space Law 204 referring to U.S. Commercial Space Launch Competitiveness Act (n 67); see also discussion in Mariella Moon, 'Luxembourg's asteroid mining law takes effect August 1st', (Engadget 30 July 2017) <https://www.engadget.com/2017-07-30luxembourg-asteroid-mining-law-august-1.html>; see also Kaiser (n 108) 282-286.

113 Brian Dunbar, 'The Artemis Accords', (National Aeronautics and Space Administration, 16 May 2020) <https://www.nasa.gov/specials/artemis-accords/img/Artemis-Accords_v7_print.pdf>

114 Kaiser (n 112) 283 referring to Outer Space Treaty (n 6). For a detailed analysis of art II, see Steven Freeland and Ram Jakhu, 'Article II of the 1969 Outer Space Treaty' in Stephan Hobe, Bernhard Schmidt-Tedd and Kai-Uwe Schrogl (eds), Cologne Commentary on Space Law, Volume I-Outer Space Treaty (Carl Heymanns Verlag 2009) 44-63.

115 See for example Kaiser (n 112) 282-283 referring to U.S. Commercial Space Launch Competitiveness Act (n 67) and Outer Space Treaty (n 6).

116 Kaiser (n 112) 282 referring to U.S. Commercial Space Launch Competitiveness Act (n 67) and Outer Space Treaty (n 6); see also Mariella Moon, 'Luxembourg's asteroid mining law takes effect August 1st' (Engadget, 30 July 2017) <https://www.engadget.com/2017-07-30-luxembourg-asteroid-mining-lawaugust-1.html>

117 Kaiser (n 112), 282-283 referring to U.S. Commercial Space Launch Competitiveness Act (n 67) and Outer Space Treaty (n 6); see generally Steven Freeland and Ram Jakhu, 'What's human rights got to do with outer space? Everything!' in Rafael Moro-Aguilar, PJ Blount \& Tanja Masson-Zwaan (eds), Proceedings of the International Institute of Space Law 2014 (Eleven International 2014) 365, 369. 
means. ${ }^{118}$ The authors of this article are not in entire agreement with that perspective, believing the situation to be more nuanced and requiring a more detailed multilateral understanding. It is pertinent to note also that it does stand in contrast to the relevant terms of the Moon Agreement of 1979 (to which the US is not a State Party and therefore is not bound). ${ }^{119}$ That agreement provides:

Neither the surface nor the subsurface of the moon, nor any part thereof or natural resources in place, shall become property of any State, international intergovernmental or non-governmental organization, national organization or non-governmental entity or of any natural person. The placement of personnel, space vehicles, equipment, facilities, stations and installations on or below the surface of the moon, including structures connected with its surface or subsurface, shall not create a right of ownership over the surface or the subsurface of the moon or any areas thereof. The foregoing provisions are without prejudice to the international regime referred to in paragraph 5 of this article. ${ }^{120}$

The Moon Agreement is, however, only binding among only those 18 States who have ratified it. ${ }^{121}$ UNCOPUOS continues to consider the issues around the 'exploration, exploitation and utilization of space resources' and has mandated for 'scheduled informal consultations' on the matter. ${ }^{122}$

The obvious point for a human rights analysis of space mining is that space belongs to 'everyone'. Article III of the Outer Space Treaty requires that:

States Parties to the Treaty shall carry on activities in the exploration and use of outer space, including the Moon and other celestial bodies, in accordance with international law, including the Charter of the United Nations, in the interest of maintaining international peace and security and promoting international cooperation and understanding. ${ }^{123}$

There are a number of conflicting rights that arise here. On the one hand, international law does recognise a sovereign right to natural resources, which has long been accepted. ${ }^{124}$ On the other, little is known about the potential impact of mining in space on the stability of both the space and Earth environments. This is potentially problematic in several ways, including in the context of 'emerging rights to a clean and healthy environment' ${ }^{125}$ Given

118 Kaiser (n 112), 283-284.

119 ibid 284-285, citing Moon Agreement (n 13).

${ }^{120}$ Moon Agreement (n 13) art 11(3).

121 ibid. Note the Moon Agreement has to date been ratified by Armenia, Australia, Austria, Belgium, Chile, Kazakhstan, Kuwait, Lebanon, Mexico, Morocco, Netherlands, Pakistan, Peru, Philippines, Saudi Arabia, Turkey, Uruguay and Venezuela whilst France, Guatemala, India and Romania, are signatories; see 'Status of International Agreements relating to Activities in Outer Space' (United Nations Office for Outer Space Affairs, 27 January 2021) <https://www.unoosa.org/oosa/en/ourwork/spacelaw/treaties/status/index.html>; and COPUOS, 'Report of the Committee on the Peaceful Uses of Outer Space' (2019) UN Doc A/74/20.

122 Report of the Committee on the Peaceful Uses of Outer Space (n 103) 257-258; UNGA 'Report of the Legal Subcomittee on its fifty-eight session, held in Vienna from 1 to 12 April 2019' UN GAOR 62 ${ }^{\text {nd }}$ Session UN Doc A/AC.105/1203 (2019); United Nations, 'Legal Subcommittee 2020: Fifty-ninth session (23 March - 3 April 2020) CANCELLED' (United Nations Office for Outer Space Affairs, 19 August 2020) <https://www.unoosa.org/oosa/en/ourwork/copuos/lsc/2020/index.html>

${ }^{123}$ Freeland and Jakhu (n 117), citing Outer Space Treaty (n 6) art 3.

124 UNGA Res 1803 (XVII) (17 December 1973).

${ }^{125}$ Experts' Meeting on Scientific Progress (n 56) 6. 
this uncertainly, the precautionary approach and the principle of intergenerational equity may be relevant to the extent that they might be applicable to activities carried on in outer space. Naturally, however, there are questions as to how and to what extent these (and other 'terrestrial' international law principles) can be adapted to appropriately apply to the unique (legal) environment of space.

The precautionary approach urges caution where environmental outcomes are uncertain. One of the better-known iterations of the principles can be found in Principle 15 of the Rio Declaration on Environment and Development in 1992:

In order to protect the environment, the precautionary approach shall be widely applied by States according to their capabilities. Where there are threats of serious or irreversible damage, lack of full scientific certainty shall not be used as a reason for postponing cost-effective measures to prevent environmental degradation. ${ }^{126}$

Since then, the principle has gained recognition in a plethora of multilateral environmental agreements and in domestic laws and policies, including those that deal with 'climate change, biodiversity, endangered species, fisheries management, wildlife trade, food safety, pollution controls, chemicals regulation, exposure to toxins, and other environmental and public health issues' ${ }^{127}$ The precautionary approach might possibly be relevant, although not necessarily directly applicable, to human rights and to human activity in outer space, particular given that so much is unknown as to the environmental consequences for Earth of destabilising the Moon through, for example, mining activities.

Further, a related concept, the principle of intergenerational equity, is based on the notion that every generation holds the Earth in common not only with members of the present generation, but also with other generations. ${ }^{128}$ In turn, the principle calls for fairness between 'generations in the use and conservation of the environment and its natural resources'. ${ }^{29}$

In international law, the principle builds upon the use of equity. In short, equity in this context requires 'that each generation pass on the planet in no worse condition than received and have equitable access to its resources. ${ }^{130}$ This, and other concerns, give context to calls for 'great swathes of the solar system' to be 'preserved as official "space wilderness" to protect planets, moons and other heavenly bodies from rampant mining and other forms of industrial exploitation'. For example, one proposal 'calls for more than $85 \%$ of the solar system to be placed off-limits to human development'. ${ }^{131}$

In this regard, it is pertinent also to note that Article 4 of the Moon Agreement specifically requires that '[d]ue regard shall [inter alia] be paid to the interests of present and future generations ...' Notwithstanding that, as noted above, this treaty has a low

${ }^{126}$ UNGA 'Report of the United Nations Conference on Environment and Development' UN Doc A/CONF.151/26 (Vol. I) (1992) principle 15 (Rio Declaration on Environment and Development).

127 Deborah Peterson, 'Precaution: principles and practice in Australian environmental and natural resource management' (Productivity Commission Presidential Address 50th Annual Australian Agricultural and Resource Economics Society conference, New South Wales, February 2006) 5.

${ }^{128}$ Edith Brown Weiss, 'Intergenerational Equity', Max Planck Encyclopedia of Public International Law (2020) <https://opil.ouplaw.com/view/10.1093/law:epil/9780199231690/law-9780199231690-e1421>

129 ibid.

${ }^{130}$ Edith Brown Weiss, 'Climate Change, Intergenerational Equity, and International Law' (2008) 9 Vermont Journal of Environmental Law 615, 622-23.

131 Ian Sample, 'Protect solar system from mining 'gold rush', say scientists', (The Guardian, 13 May 2019) $<$ https://www.theguardian.com/science/2019/may/12/protect-solar-system-space-mining-gold-rushsay-scientists> 
number of ratifications, its terms had been agreed through a consensus process at UNCOPUOS, including reference to this recognition of the concept of intergenerational equity, already in the 1970s.

The consequences for the space environment of such resource extraction activities are not at all well understood. We are simply not yet able to accurately forecast the impacts of disruptive extraction processes on celestial bodies, and the effects that this may also have on intergenerational equity.

In sum, the legalities of space mining turn on interpretation of the Outer Space Treaty, the Moon Agreement (for its small number of States Parties) and how the 'global commons' principle manifests in outer space. ${ }^{132}$ This raises environmental human rights issues, as well as broader considerations around the precautionary principle and principles of intergenerational equity. For example, some mining activities on Earth have negatively impacted the enjoyment of the right to health of local communities, as well as workers, and in some cases, have also impeded access to clean and safe food and water. Very little is known of the impact mining in space would have on the stability of Earth's environment, and therefore, in turn, on the enjoyment of the right to health.

Further, tensions over natural resource exploitation on Earth have escalated international relations into armed conflicts before in human history. There is a genuine concern the same risks exist in relation to competing claims to resources in outer space. This in turn leads us to now consider the weaponization and militarization of space.

\section{Militarisation and Weaponization of Space}

Since the launch of Sputnik 1 in 1957, humankind has to a large degree respected the 'peaceful purposes' requirement that underpins the United Nations Space Treaties. We have not seen a space object destroyed in anger - although several States have deliberately destroyed their own satellites ${ }^{133}$ - and space has not become a theatre of warfare, notwithstanding more recent calls by some for it to be regarded as a 'war fighting domain', a categorization that, in the authors' opinion at least, should be resisted and rejected whenever possible. ${ }^{134}$

From this perspective, space has actually 'worked' well, itself quite a remarkable feat of law and the rule of law, and its facilitation of responsible norms of behaviour, given the rapid development of (military) space technology over the past five decades. In this regard, space law has played a positive role, by allowing for - and not unduly restricting - the development of space-related technology and ensuing human rights benefits, whilst discouraging and proscribing bad behaviour, which would have negative consequences on the enjoyment of human rights.

For example, it is evident that the utilisation of space technology has allowed for significantly better access to information, communications, technology and infrastructure for less developed countries, a transformation that has been significantly enhanced

132 Steven Freeland Interview (n 112). Note, however, that the recent Executive Order issued by the Trump Administration on 6 April 2020 asserted that, from the perspective of the United States, outer space was not to be regarded as a 'global commons'.

133 As is well known, the latest of these 'tests' was conducted by India on 27 March 2019 - ironically three days before the start of the $58^{\text {th }}$ session of the Legal Subcommittee of UNCOPUOS - when it deliberately destroyed by kinetic means an Indian satellite orbiting at approximately 285 kilometres above the Earth; see Marco Langbroek, 'Why India's ASAT Test was Reckless' (The Diplomat, 30 March 2019) <https://thediplomat.com/2019/05/why-indias-asat-test-was-reckless/>

134 See Steven Freeland, 'The US Plan for a Space Force risks escalating a 'Space Arms Race' (The Conversation, 10 August 2018) <https://theconversation.com/the-us-plan-for-a-space-force-risksescalating-a-space-arms-race-101368> 
through the establishment, in the 1970s, of INTELSAT, whose original purpose was to provide satellite services and infrastructure to such countries in a way that would promote higher standards of living and conditions of economic and social progress. ${ }^{135}$

At the same time, the existing legal regime has not prevented the development of military technology capable of utilizing outer space. Whilst there are some restrictions in the Outer Space Treaty, these were specified in relatively general terms and were open to divergent interpretation as to what they did (and did not) prohibit. This is not entirely surprising, given the time that the instrument was concluded, and that the development of space-related technology was, at least initially, inextricably related to military strength both in reality and to influence the perception of others.

Indeed, it is no coincidence that the space race emerged at the height of the Cold War, when both the United States and the Soviet Union strove to flex their respective technological 'muscles'. The early stages of human space activity coincided with a period of quite considerable tension, with the possibility of large scale and potentially highly destructive military conflict between the (space) superpowers of the time always lurking in the background.

The conventional obligations and restrictions that were eventually agreed and codified in the major space treaties addressed, in part, specific military and weaponsrelated aspects of space activities. However, they were, as described below, neither entirely clear nor sufficiently comprehensive to meet all of these challenges. The Moon and celestial bodies were declared as to be used 'exclusively for peaceful purposes'. ${ }^{136}$ Whilst most space scholars would subsequently interpret the relevant provisions as prohibiting military space activities in outer space, this was not followed by the practice of those who actually had space capability. Indeed, with the benefit of hindsight, it is now clear that space has been utilized to support terrestrial military activities almost from the commencement of the space age.

Since those early days, the situation has, if anything, become significantly more complex, with potentially drastic and catastrophic consequences, including for the enjoyment of human rights relating to life and safety. Just as the major space-faring nations have been undertaking what might be termed 'passive' military activities in outer space, outer space is increasingly now being used as part of active engagement in the conduct of armed conflict. ${ }^{137}$ Not only is information gathered from outer space - through, for

135 INTELSAT was created through a multilateral treaty with the desire to produce telecommunications 'for the benefit of all [hu]mankind'; Agreement relating to the International Telecommunications Satellite Organization (adopted 20 August 1971, entered into force 12 February 1973) UNTS 1220 (INTELSAT); The United States advocated at the United Nations for the establishment of the international organisation to provide a single global public telecommunications network. See Bert Rein and Carl Frank, 'The Legal Commitment of the United States to the INTELSAT System' (1989) 14 North Carolina Journal of International Law 219. Alongside ambitions of social progress, INTELSAT provided high quality telecommunication that were economically viable through international collaboration of governments and private enterprise; FG Nixon, 'Intelsat: A Progress Report on the Move toward Definitive Agreements' (1970) 20 The University of Toronto Law Journal 380, 383. INTELSAT was privatised in 2001, and the International Telecommunications Satellite Organization (ITSO) continues to fulfil its international obligations; 'About Us' (ITSO, 2020) <https://itso.int/about-us/>

136 Outer Space Treaty (n 6) art 4.

137 See for example Jackson Maogoto and Steven Freeland, 'The Final Frontier: The Laws of Armed Conflict and Space Warfare' (2007) 23 Connecticut Journal of International Law 165; David Simonds, 'A New Arms Race in Space?' (The Economist, 25 January 2007) <https://www.economist.com/leaders/2007/01/25/a-new-arms-race-in-space>; Thomas Ricks, 'Space Is Playing Field for Newest War Game; Air Force Exercise Shows Shift in Focus', (The Washington

Post, 
example, the use of remote satellite technology and communications satellites as discussed above - used to plan military engagement on Earth, but also space assets are now used to direct military activity and represent an integral part of the military hardware of the major powers.

Sadly, it is now within the realms of reality that outer space may itself become an emerging theatre of warfare. Designations of space as simply to be thought of as 'contested, congested and competitive' ${ }^{138}$ with war in space described in some military circles as 'inevitable', are dangerously self-fulfilling and largely self-defeating: all States, particularly the major space-faring ones, will suffer if activities in space are undertaken in such an irresponsible manner as to cross certain "red lines" of accepted behaviour.

In the specific context of human rights, it is accepted that the 'development of weapons technologies endangers the enjoyment of human rights worldwide', ${ }^{139}$ and the weaponization of space is no different. In particular, the militarisation and weaponization of space raises concerns for specific rights, such as the right to life, the right to a safe environment, the right to development, the right to peace and others. ${ }^{140}$ Moreover, in the event that military activities in space lead to irreversible consequences that compromise humankind's ability to utilize space in the future, this will undoubtedly impact adversely on the myriad other rights referred to in this article that are connected to sustainable uses of space for present and future generations.

Clearly, resort to irresponsible behaviour in space has the potential to give rise to consequences that are beyond contemplation and, given that the authors believe the future of humanity is inextricably tied to our continuous use of space for peaceful purposes, the ongoing militarization and threatened weaponization of space represents a most significant challenge. Interestingly, such developments are giving rise to a new human rights discourse, where some commentators are now seeking to explore what they see as a development towards human rights principles that protect from 'physical or psychological threats' from above. ${ }^{141}$

\section{E. Assertion of jurisdiction extra-terrestrially}

Jurisdiction is a technical means of establishing public authority, ${ }^{142}$ including over humans and human rights. Therefore, considering jurisdictional practice in space is a means of gaining insight as to the nature of public authority over humans and human rights in space. As noted in our recap of human rights law at II(a) above, as a matter of customary international law, States are entitled to exercise jurisdiction on three main bases: territoriality, nationality, and universality.

Put simply, the nationality principle can provide a State with grounds for jurisdiction where a victim (passive nationality), or a perpetrator (active nationality), is a national of that State. The territoriality principle may be invoked where conduct either takes place

<https://www.washingtonpost.com/archive/politics/2001/01/29/space-is-playing-fieldfor-newestwar-game/938e9674-0c3b-4d66-b67b-e3195b1275fd/>

138 See for example Government of Australia, 'Working Paper by Australia to the UN Disarmament Commission 2018 Working Group on Transparency and Confidence Building Measures in Outer Space Activities' (2018) Document A/CN.10/2018/WG.II/CRP.1 <https://www.un.org/disarmament/wpcontent/uploads/2018/04/A-CN.10-2018-WG.2-CRP.11.pdf>

139 Experts' Meeting on Scientific Progress (n 56) 6.

140 See generally UDHR (n 10); ICCPR (n 9); ICESCR (n 9).

141 See Nick Grief, Shona Illingworth, Andrew Hoskins and others, 'Opinion: The Airspace Tribunal: Towards a New Human Right to Protect the Freedom to Exist Without Physical or Psychological Threat from Above' (2018) 3 European Human Rights Law Review 201, 201-207.

142 Shaunnagh Dorsett and Shaun McVeigh, 'Jurisprudences of Jurisdiction: Matters of Public Authority' (2014) 23 Griffith Law Review 569, 588. 
within a nation's borders (subjective territoriality), or the effects of the conduct are felt within the borders (objective territoriality). The universality principle is reserved for conduct recognised as a crime under international law, such as piracy, genocide and crimes against humanity. International law also recognises a 'protective principle', wherein a State can assert jurisdiction over foreign conduct that threatens national security. There are also claims to an 'effects principle', by which jurisdiction over extraterritorial conduct is enjoyed because the effects of that conduct are felt by a State, although this is sometimes considered controversial.

In our 2020 article, 'Star Laws: Criminal Jurisdiction in Outer Space', ${ }^{143}$ we considered the issue of the exercise of extra-territorial criminal jurisdiction in outer space. In so doing, we identified circumstances in which the law currently appears to permit the assertion of domestic criminal law to conduct occurring in space. For example, the IGA has express provisions on jurisdiction over criminal matters in outer space. The provisions only apply on board the International Space Station and are only binding on the 'Partner States'. Article 22, titled 'Criminal Jurisdiction' (and commencing with the words: 'in view of the unique and unprecedented nature of this particular international cooperation in space'), provides for nationality-based jurisdiction. Article 22(1) states that:

Canada, the European Partner States, Japan, Russia, and the United States may exercise criminal jurisdiction over personnel in or on any flight element who are their respective nationals.

This is an example of active-nationality jurisdiction, whereby authority is asserted by a State over its national. Article 22(2) provides for passive nationality jurisdiction, but only where the 'Partner State' of which the perpetrator is a national either 'concurs' in such exercise or fails to provide assurances that it will prosecute the perpetrator itself - the latter being somewhat akin to an 'unwilling or unable' type of jurisdiction. This statement of passive personality jurisdiction is also in the context of specific types of conduct. Specifically, Article 22(2) provides:

In a case involving misconduct on orbit that: (a) affects the life or safety of a national of another Partner State or (b) occurs in or on or causes damage to the flight element of another Partner State, the Partner State whose national is the alleged perpetrator shall, at the request of any affected Partner State, consult with such State concerning their respective prosecutorial interests. An affected Partner State may, following such consultation, exercise criminal jurisdiction over the alleged perpetrator provided that, within 90 days of the date of such consultation or within such other period as may be mutually agreed, the Partner State whose national is the alleged perpetrator either: (1) concurs in such exercise of criminal jurisdiction, or (2) fails to provide assurances that it will submit the case to its competent authorities for the purpose of prosecution.

While the exercise of extraterritorial jurisdiction makes sense in an interconnected world and can help minimize impunity for cross-border or extra-terrestrial criminal activity, there nonetheless remain some concerns for human rights. For example, assertions of the passive nationality principle without a meaningful territorial nexus may create issues for due process rights and the rule of law, particularly given the terms and content of the law

${ }^{143}$ See Danielle Ireland-Piper and Steven Freeland, 'Star Laws: Criminal Jurisdiction in Outer Space' (2020) 44 Journal of Space Law 44. 
is not always 'knowable' (or accessible) to a citizen of a different nationality. This is particularly so given, as a matter of international human rights law, the principle of double jeopardy only applies within a state and not as between them. ${ }^{144}$ In theory, this might mean an accused could be subject to multiple proceedings.

Further, most assertions of extra-territorial jurisdiction are based on the premise that 'ordinary' terrestrial (national) criminal law and procedure can continue to apply in space. However, this may not be practical given the time, distances, and expense facing the practical realities of enforcement jurisdiction beyond Earth. Article 14 of the ICCPR provides for a number of 'fair trial' rights and Article 9 of the ICCPR is relevant to an exercise of extra-territoriality because it prohibits arbitrary arrest or detention. ${ }^{145}$

It may be that these rights need specific 'unpacking' in the context of crimes alleged to have been committed in outer space in order to provide guidance and clarity as to what arbitrariness and detention might look like extra-terrestrially, or when an accused person returns to Earth and multiple States have interest in the alleged conduct. It also gives rise to the broader question, which is beyond the scope of this article, as to what specific laws should be developed to apply more suitably to the interactions between human beings living in future permanent human settlements in space, for example on the Moon.

\section{Conclusion}

The task we have set ourselves in this introductory article is to broadly consider some of the human rights implications of human activity in outer space. In so doing, we have identified that access to space and remote-sensing technologies have implications for the right of everyone to enjoy the benefits of scientific progress and its applications, and other related rights, but also for the right to privacy. The management of space debris and future ambitions for space mining have implications for the principle of intergenerational equity and on the emerging right to a clean and safe environment.

The weaponization and militarization of space have clear implications on the right to life and, more broadly, on the prohibition of the use of force and the principles of international humanitarian law, including the principles of military necessity, proportionality, unnecessary suffering, and distinction. Turning to procedural rights, we also observed that the assertion by States of domestic criminal jurisdiction in outer space raises issues for due process, detention and fair trial rights.

We have written this article using a necessarily broad brush. It, of course, does not represent a complete exposition of human rights law in outer space. Instead, what we hope to have achieved, is to make the point that increasing human activity in outer space does have tangible consequences for human rights law here on Earth and to generate further discussion on this issue. In turn, this may require the development of cohesive and specialist regimes addressing the nexus between human rights and space. We look forward to participating in, and commenting on, the research of others who will look to explore this nexus in more express detail. There is clearly much work to be done in this regard and we hope that these brief thoughts will facilitate further discussion.

144 See OHCHR, 'Views: Communication No 204/1986' (1987) UN Doc CCPR/C/OP/2. This is somewhat nuanced under international criminal law, which applies the principle of ne bis in idem as between a state and an international criminal tribunal, such as the International Criminal Court; see Rome Statute of the International Criminal Court (adopted 17 July 1998, entered into force 1 July 2002) 2187 UNTS 90 (Rome Statute) art 20.

${ }^{145}$ ICCPR (n 9) art 9 which specifies that ' $[n]$ o one shall be deprived of his liberty except on such grounds and in accordance with such procedure as are established by law'. 
Human Rights and Space: Reflections on the Implications of Human Activity in Outer Space on Human Rights Law

127

$*$

www.grojil.org 